\title{
Dynamic integrated water quality modelling: A case study of the Lambro River, northern Italy
}

\author{
L Benedetti ${ }^{1 *}$, J Meirlaen ${ }^{1}$, F Sforzi ${ }^{1}$, A Facchi ${ }^{2}$, C Gandolfi' and PA Vanrolleghem ${ }^{1}$ \\ ${ }^{1}$ BIOMATH, Ghent University, Coupure Links 653, B-9000 Gent, Belgium \\ ${ }^{2}$ Institute of Agricultural Hydraulics, University of Milan, Via Celoria 2, 20133 Milano, Italy
}

\begin{abstract}
In this paper an integrated modelling approach is presented and applied to a $26 \mathrm{~km}$ stretch of the Lambro River downstream of the Merone Wastewater Treatment Plant in northern Italy. The sub-models used (ASM1 for the treatment plant and RWQM1 for the river) have been implemented in the WEST ${ }^{\circledR}$ simulator. Hydraulics and quality processes of the Lambro River have been modelled with a 'tanks in series' approach. The purpose of this study is to model the effect on river water quality of an insufficient treatment capacity of the WWTP. The plant was constantly operating at its maximum hydraulic capacity, leading to a daily bypass of dry weather wastewater, which imposed a marked diurnal cycle on pollutant concentrations in the river. The assessment of the actual WWTP upgrade has confirmed its beneficial effect on the river water quality.
\end{abstract}

Keywords: ASM1, integrated modelling, LAS, model interfaces, RWQM1

\section{Introduction}

Integration of the different components of an urban drainage system in a single model allows better understanding of the operation of the system as a whole, and of the mutual interaction between its components. This is clearly essential for evaluation of the system performance, as well as for detection of its weak points, in the context of environmentally and economically sound planning and management practices (Rauch et al., 1998). It is also a necessary step for the implementation of real-time control strategies for the urban drainage system (Meirlaen et al., 2001; Vanrolleghem et al., 2005a).

Schütze et al. (1999) used different existing software packages together in the SYNOPSIS tool (software package for SYNchronous OPtimisation and SImulation of the urban wastewater system). The sewer and treatment plant simulation was run in parallel - as a single model in contrast to simulation in series, with sewer simulation followed by wastewater treatment plant (WWTP) simulation - generating influent files for the river model. However, by implementing the system in this way, it was not possible to use the water quality of the river in a control loop for the sewer system or treatment plant. Rauch and Harremoës (1999) used genetic algorithms to optimise the oxygen concentration in the river through operation of the WWTP, but did not use a parallel model in which the current river states can be used to trigger a valve or pump in the drainage system, in order to store wastewater or stormwater until the river conditions were acceptable for discharge. Taylor et al. (2000) describe the Integrated Catchment Simulator, connecting different existing software packages. Automatic connections and data exchange between different software packages represent a big step forward; however, the models that have been used are hydraulically very detailed, resulting in long calculation times and large output files. Recent examples of integrated parallel modelling on

* To whom all correspondence should be addressed.

喵 +329264 5937; fax: +329264 6220;

e-mail: 1bene@biomath.ugent.be

Received 16 October 2006; accepted in revised form 23 August 2007. a single software platform can be found in Erbe and Schütze (2005) and Solvi et al. (2006).

One of the main problems when developing an integrated model is the incompatibility between state variables, processes and parameters used in the different sub-models, for example with the treatment plant model - where variables are typically based on chemical oxygen demand (COD) like in the Activated Sludge Model No. 1 (ASM1), a dynamic model describing carbon and nitrogen removal by active biomass (Henze et al., 2000) - and the river water quality model, traditionally based on biological oxygen demand (BOD) like in QUAL2E (Brown and Barnwell, 1987). Maryns and Bauwens (1997) tried to avoid the problem by using the ASM1 model to model river conditions but without satisfactory results. To tackle this problem more fundamentally, the International Water Association (IWA) Task Group on River Water Quality has developed a COD-based model, the River Water Quality Model No.1 (RWQM1) (Reichert et al., 2001), which has already been used to model river water quality in South Africa (Deksissa et al., 2003). The state variables of RWQM1 model are more like those of the ASM1 model, but some differences still remain because the full RWQM1 model can describe more components than the ASM1 model (e.g. algae growth).

As environmental conditions in sub-systems are different, the main processes will also differ because organisms behave differently depending on the environment. For instance, nitrifying bacteria in an activated sludge (AS) system are confronted with high competition for oxygen with heterotrophic organisms, while in the river system this competition is reduced. Therefore, when using two models with different state variables, an interface needs to be developed in order to translate the state variables of the original model to those of the destination model in a consistent way. This interface needs to contain all available knowledge about the different states in the two models and different environmental conditions in the two sub-systems, and requires closed elemental balances, in this case for $\mathrm{COD}, \mathrm{C}, \mathrm{N}$, $\mathrm{P}, \mathrm{O}$ and $\mathrm{H}$.

In this paper an integrated modelling approach is presented and applied to a $26 \mathrm{~km}$ stretch of the Lambro River downstream 

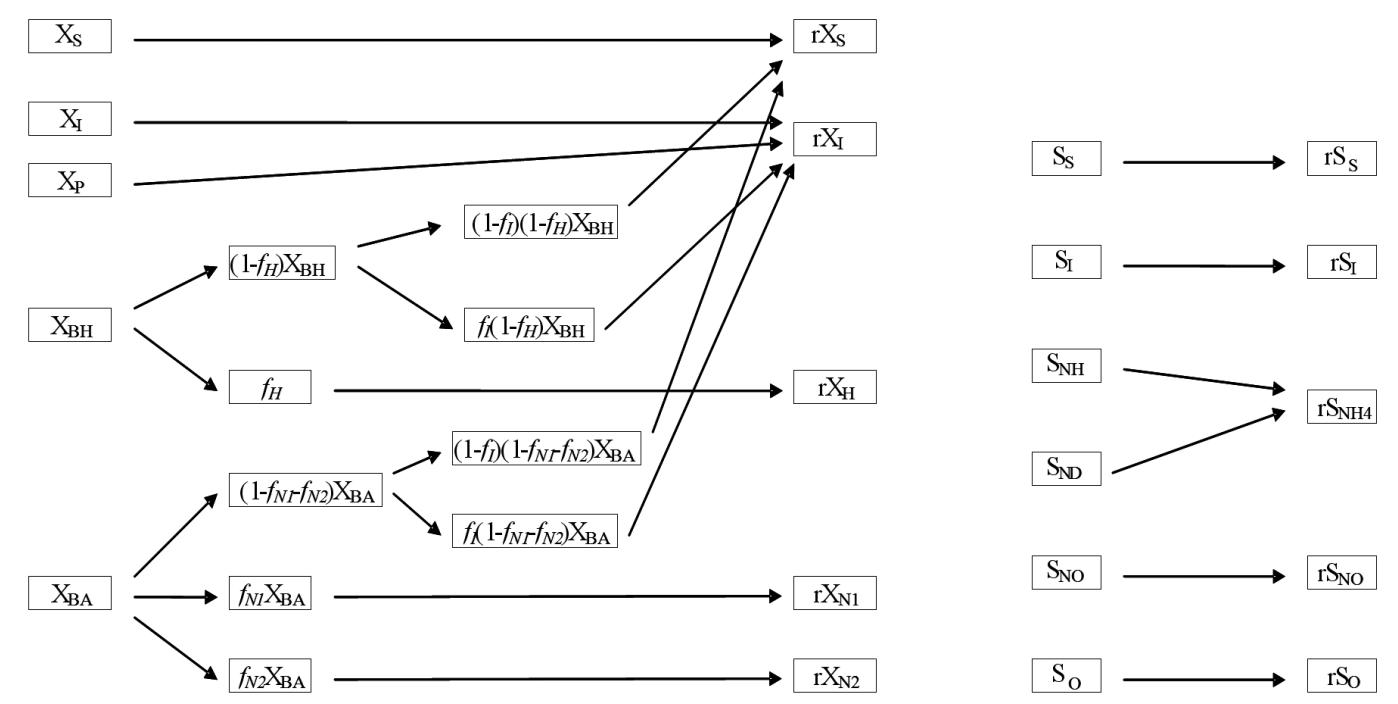

Figure 1

Fate of particulate biomass (left) and of soluble components (right) from state variables of ASM1 to RWQM1; for explanation of symbols see Table 1

of the Merone WWTP in northern Italy. Dispersion and water quality of the Lambro have been modelled with a tanks-inseries approach. The entire system, including sub-models, used to describe the treatment plant and river in the study area (respectively ASM1 and RWQM1), has been implemented in the WEST $^{\circledR}$ software (Vanhooren et al., 2003), which is a modelling and simulation platform for different processes (wastewater, rivers, fermentation, etc.). The purpose of the study is to model the effect on river water quality of insufficient treatment capacity at the Merone WWTP. The WWTP was constantly operating at its maximum hydraulic capacity with the consequent daily bypass of wastewater even in dry weather (no stormwater added to the flow), imposing a marked diurnal cycle in pollutant concentrations in the river for a considerable distance downstream of the plant. Linear alkylbenzene sulphonate (LAS), a common pollutant present in detergents, and boron have been used respectively as an indicator of pollution and a tracer. An assessment has been made to evaluate the beneficial effect of the construction of further treatment volumes in the WWTP on the river water quality.

\section{Method}

\section{The model interface}

The interface consists of algebraic equations that express concentration inputs into the river in terms of concentration outputs from the sewer or WWTP.

RWQM1 uses COD as a measure for organic pollution, which simplifies integration with the COD-based ASM models. Moreover, RWQM1 has closed mass balances for COD, and closed elemental balances for C, N, P, O and H. Since these are important properties, the goal was to keep these in the new interface.

The way in which particulate matter and soluble components are translated when going from the treatment plant model to the river model is shown in Fig. 1.

Some state variables can be easily translated from the AS system to the river conditions. Slowly and readily biodegradable substances will probably remain biodegradable upon entering the river, assuming the presence of heterotrophic bacteria and aerobic conditions in the river. Not all active biomass from the sewer or AS system remains active in the river, since environmental conditions in the sewer or treatment plant and the river

\begin{tabular}{|l|l|}
\hline \multicolumn{2}{|l|}{ Explanation of symbols used in Fig. 1 } \\
\hline $\begin{array}{l}\text { Sym- } \\
\text { bol }\end{array}$ & Meaning \\
\hline $\mathrm{X}_{\mathrm{S}}$ & Slowly biodegradable substrate in the AS \\
\hline $\mathrm{X}_{\mathrm{I}}$ & Particulate inert organic matter in the AS \\
\hline $\mathrm{X}_{\mathrm{P}}$ & Particulate products arising from biomass decay in the AS \\
\hline $\mathrm{X}_{\mathrm{BH}}$ & Active heterotrophic biomass in the AS \\
\hline $\mathrm{X}_{\mathrm{BA}}$ & Active autotrophic biomass in the AS \\
\hline $\mathrm{rX}_{\mathrm{S}}$ & Particulate organic matter in the river \\
\hline $\mathrm{rX}_{\mathrm{I}}$ & Particulate inert organic matter in the river \\
\hline $\mathrm{rX}_{\mathrm{H}}$ & Active heterotrophic biomass in the river \\
\hline $\mathrm{rX}_{\mathrm{N} 1}$ & Active first step nitrifiers (ammonia to nitrite) in the river \\
\hline $\mathrm{rX}_{\mathrm{N} 2}$ & Active second step nitrifiers (nitrite to nitrate) in the river \\
\hline $\mathrm{f}_{\mathrm{I}}$ & $\begin{array}{l}\text { Fraction of dead AS biomass becoming inert matter in the } \\
\text { river }\end{array}$ \\
\hline $\mathrm{f}_{\mathrm{H}}$ & $\begin{array}{l}\text { Fraction of heterotrophic AS biomass still active in the } \\
\text { river }\end{array}$ \\
\hline $\mathrm{f}_{\mathrm{N} 1}$ & Fraction of first step nitrifiers AS still active in the river \\
\hline $\mathrm{f}_{\mathrm{N} 2}$ & Fraction of second step nitrifiers AS still active in the river \\
\hline $\mathrm{S}_{\mathrm{S}}$ & Readily biodegradable substrate in the AS \\
\hline $\mathrm{S}_{\mathrm{I}}$ & Soluble inert organic matter in the AS \\
\hline $\mathrm{S}_{\mathrm{NH}}$ & NH ${ }_{4}^{+}+$NH ${ }_{3}$ nitrogen in the AS \\
\hline $\mathrm{S}_{\mathrm{ND}}$ & Soluble biodegradable organic nitrogen in the AS \\
\hline $\mathrm{S}_{\mathrm{NO}}$ & Nitrate and nitrite nitrogen in the AS \\
\hline $\mathrm{S}_{\mathrm{O}}$ & Dissolved oxygen in the AS \\
\hline $\mathrm{rS}_{\mathrm{S}}$ & Readily biodegradable substrate in the river \\
\hline $\mathrm{rS}_{\mathrm{I}}$ & Soluble inert organic matter in the river \\
\hline $\mathrm{rS}_{\mathrm{NH} 4}$ & NH ${ }_{4}^{+}+$NH nitrogen in the river \\
\hline $\mathrm{rS}_{\mathrm{NO}}$ & Nitrate and nitrite nitrogen in the river \\
\hline $\mathrm{rS}_{\mathrm{O}}$ & Dissolved oxygen in the river \\
\hline &
\end{tabular}

are usually different in terms of temperature, food, light intensity, etc. (Féray and Montuelle, 2002). In the interface between models, biomass is split into a part that remains active, a part that is inert and a part that consists of slowly biodegradable organic matter.

Autotrophic biomass is modelled as first and second step nitrifiers in RWQM1, but only as one group of organisms in ASM1. In the interface the incoming autotrophic biomass is split into two active groups (with respective surviving fractions $\mathrm{f}_{\mathrm{N} 1}$ and $\mathrm{f}_{\mathrm{N} 2}$ ), while the remaining (dead) part is split into slowly 
biodegradable and inert particulate organic matter. The surviving fractions are found by calibration, since so far no values are available in literature; only the relationship $\mathrm{f}_{\mathrm{N} 1}=3 \cdot \mathrm{f}_{\mathrm{N} 2}$ (Focht and Verstraete, 1977) can be useful as a first approximation. Dead biomass is split into two particulate fractions, one biodegradable and one inert, by means of the parameter $f_{I}$, analogous to the parameter $f_{p}$ in ASM1, even if it has to be taken into consideration that environmental conditions are different between ASM1 and RWQM1.

To calculate output concentrations of carbonates $\left(\mathrm{CO}_{2}\right.$, $\mathrm{HCO}_{3}^{-}$and $\mathrm{CO}_{3}^{2-}$ ) into the river model, the carbonate equilibrium equations have been implemented as a function of incoming alkalinity (a state variable in ASM1) and $\mathrm{pH}$ (a parameter of the interface). Soluble organic nitrogen $\left(\mathrm{S}_{\mathrm{ND}}\right.$ in ASM1) is added to $\mathrm{NH}_{4}$ in the interface output, assuming a worst-case scenario of instantaneous ammonification, and since the river model has no similar state. Variables used in RWQM1 but not in ASM1 like nitrite, particulate phosphate or algae are set by fixed parameters in RWQM1 and need to be estimated for the system under study.

After closing the above-mentioned mass balances for COD and soluble nitrogen, elemental balances still need to be closed. This is done by using compensation terms, used to compensate for a lack or surplus of elements. To this end, the elemental flux calculated from the ASM1 state variables should be compared to the elemental flux to the RWQM1 state variables. The difference between these two fluxes (either negative or positive) is the compensation term, and is added to the state chosen as the balance state for the specific element. Ideally, compensation terms should always be zero. A balance state serves as a sink or source of elements for organic compounds, e.g. if more nitrogen is present in organic matter entering the river than coming from the treatment plant, then the amount of ammonia going into the river is artificially decreased in order to close the nitrogen balance over the interface. The balance states chosen in the river model are $\mathrm{CO}_{2}$ for $\mathrm{C}, \mathrm{NH}_{4}^{+}$for $\mathrm{N}, \mathrm{HPO}_{4}^{2-}$ for $\mathrm{P}$, dissolved oxygen for $\mathrm{O}$ and $\mathrm{H}^{+}$for $\mathrm{H}$. To calculate the flux of the 5 elements coming from ASM1, the elemental composition of its different model components needs to be fixed. The $\mathrm{N}$ and $\mathrm{P}$ content were calculated according to (Henze et al., 2000), while $\mathrm{C}, \mathrm{O}$ and $\mathrm{H}$ content were calculated according to Reichert et al., 2001. The following equation illustrates the use of a compensation term for $\mathrm{N}\left(\mathrm{N}_{\text {comp }}\right)$, which in the interface is added to the outgoing $\mathrm{NH}_{4}^{+}$(the balance state for $\mathrm{N}$ ).

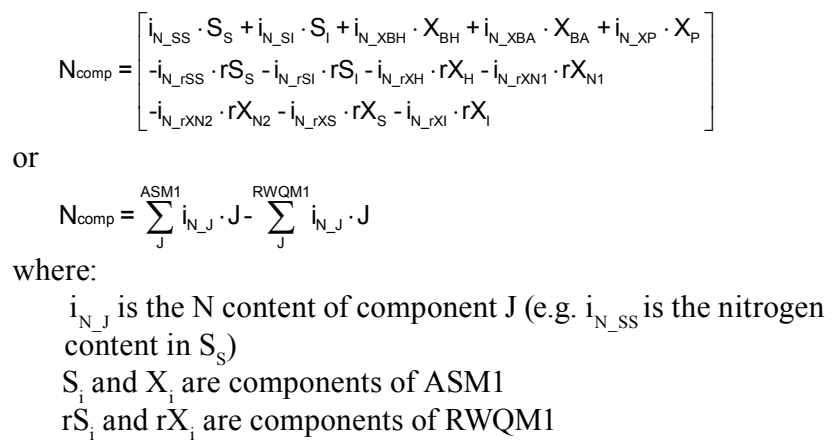

More details on this interface can be found in Benedetti et al. (2004). For a description of the newly developed systematic procedure for continuity-based interfacing method (CBIM), see Vanrolleghem et al. (2005b).

\section{Site description and monitoring activity}

The Lambro River lies to the north of Milano, Italy. The stretch under study has a length of $26 \mathrm{~km}$ and a total drained area of approximately $300 \mathrm{~km}^{2}$. Lake Pusiano, which lies just upstream, gives it a relatively steady flow regime. The most important pollution source in this stretch is the WWTP of Merone, located at the beginning of the stretch. This treatment plant receives the wastewater of approximately 120000 population equivalent. Prior to July 1998 it was operating at its maximum hydraulic capacity, with a daily overflow of dry weather wastewater (approximately $40 \%$ was regularly discharged untreated directly into the river).

All data used in the study were collected between March 1997 and May 1998, before the extension of the plant, in the context of a European research project. A 9-day study was performed at the Merone WWTP in July 1997 with the aim of evaluating plant efficiency. Twelve $\mathrm{x} 2 \mathrm{~h}$ composite samples of influent and effluent were collected over $24 \mathrm{~h}$ on the first day, while $24 \mathrm{~h}$ composite samples were collected on each of the remaining days. Samples were analysed for LAS, boron, total phosphorous, total nitrogen and suspended solids. Concerning the river sampling, 5 automatic water quality samplers were placed along the study reach between November 1997 and May 1998, in order to collect $24 \mathrm{~h}$ composite samples twice a month. One sampler was placed upstream and 4 samplers downstream of the plant, and a $6^{\text {th }}$ sampler was placed at the inlet of the WWTP. The samples were analysed for LAS, boron and a series of standard water quality variables. In order to increase the understanding of the effect of the Merone plant on the water quality downstream, two extended measurement campaigns (February 1997 in dry weather conditions, and May 1998 in wet weather conditions) were performed with the objective of following the diurnal wave of pollutant as it moved along the river stretch. Two-hourly samples were taken at 6 different stations using automatic samplers with staggered starting times. During both campaigns the flow was considered to be steady and the starting times for the samplers were selected on the basis of river travel times estimated by a steady-state hydraulic model (Gandolfi and Facchi, 1998). Two gauging stations are situated within the study river stretch. For these sites flow-rating curves (Q-h relationships) of good quality are available.

\section{Results and discussion}

\section{The Merone WWTP modelling and calibration}

Reactions in the AS units are described by the ASM1 model, with the parameters suggested in the report by Henze et al. (2000) used as a starting point. An extra component was added to the ASM1 model in order to describe the LAS behaviour in the plant. LAS is known to degrade almost completely in AS treatment plants but only in aerobic conditions (Boeije et al., 1998). A first-order removal mechanism was assumed, combined with a switching function for oxygen which turned off degradation in anoxic conditions. Corresponding oxygen uptake and growth of heterotrophic biomass was also included, while the yield was taken as being the same as the yield during degradation of $\mathrm{S}_{\mathrm{S}}$ in ASM1. The value for the degradation constant found by automatic calibration was $176 \cdot \mathrm{d}^{-1}$, in good agreement with Boeije et al. (1998) considering the different environmental conditions.

Available data were scarce and hence only an approximate calibration could be accomplished. Steady-state calibration was performed using average data from the $9 \mathrm{~d}$ study, while dynamic calibration was performed using the data from Day 9. The suspended solids concentration in the AS tanks was mainly influenced by the inert solids in the influent since these inert solids accumulate in the system, especially with the sludge age 


\section{Figure 2 Hypothesis on water flow in aerated tanks (left), and model- ling approach (right)}

Figure 3 Effect of the number of tanks on dispersion after $26 \mathrm{~km}$ (left), and longitudinal propagation of pollution wave with 47 tanks (right).
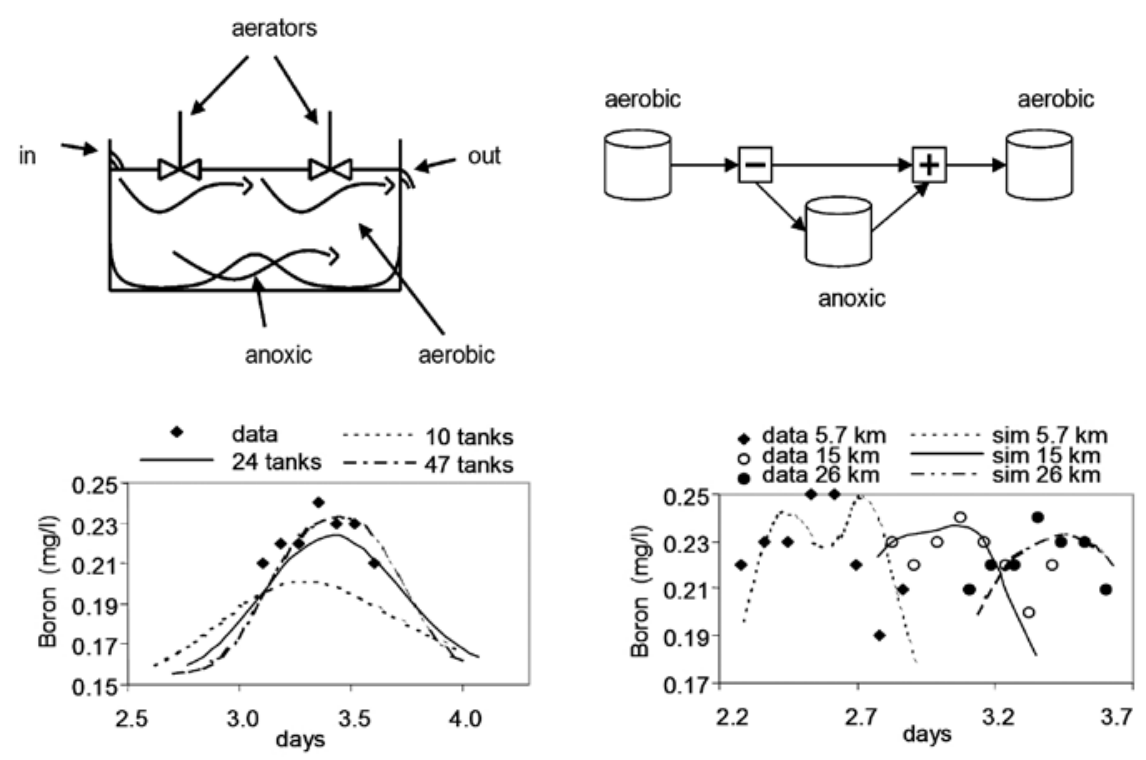

required for nitrification (Ekama and Wentzel, 2004). Good results were obtained with a ratio of $40 \%$ of $X_{I}$ and $60 \%$ of $X_{S}$ in the inlet particulates.

Although both AS tanks are aerated, total nitrogen balances indicated simultaneous nitrification and denitrification in the plant. A macro-scale idea on how water flows in a tank equipped with surface aerators is presented in Fig. 2 (left). As aeration, inflow and outflow occur at the top of the tank, the hypothesis is that some water may find a shortcut without entering the anoxic phase, and that at the bottom water has lower oxygen concentrations and flow velocities. This hypothesis was not confirmed by direct measurements, but it allows describing dead zones in a reasonable way (Alex et al., 2002). Therefore, two aerobic tanks and one anoxic tank are used in the model (Fig. 2, right, shows the modelling approach), keeping the total model volume equal to the actual WWTP volume. Total nitrogen in the effluent was mainly influenced by the anoxic volume and the flow to the anoxic tank. Parameter adjustment yielded an anoxic volume of $10 \%$ and a flow of $5 \%$ to the anoxic tank. A sensitivity analysis showed that the anoxic tank volume did not have a large influence on the effluent LAS concentration, which is the main focus of this work. This could be explained by the fact that no degradation occurs under anoxic conditions (Boeije et al., 1998), and the aerobic residence time was still sufficiently large to degrade most of the LAS.

\section{Modelling and calibration of the Lambro River}

In the case of the Lambro River, the hydraulics was modelled by using a series of tanks with variable volume. This modelling approach requires the river to be divided into stretches, in which the end of a stretch usually coincides with river discontinuities or sites where information is available as input data or required as model output (Reda, 1996). The river reach under study was initially divided into 5 stretches, with the end of each stretch coinciding with sites in which water quality data were available. Data collected in dry-weather conditions were used for this calibration.

The pollution wave of boron coming from the bypass household wastewater has been used as a tracer to select the number of tanks necessary to model the hydraulic behaviour of the Lambro River. Boron is chemically inert and is a well-established conservative tracer for use in environmental monitoring studies

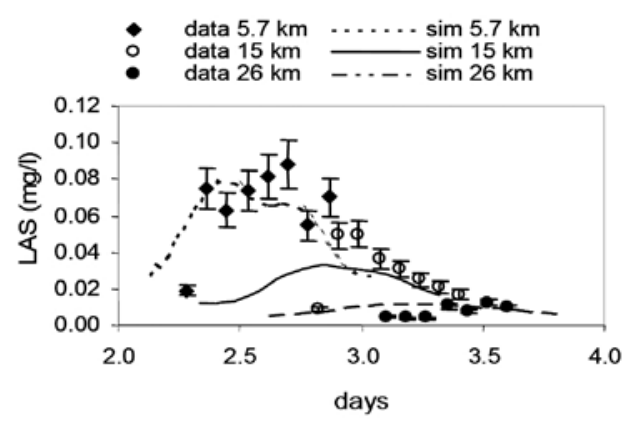

Figure 4

Simulated and measured (including bars for measurement error) LAS concentration in 3 river sections

since it is not removed significantly in sewer systems, treatment plants or rivers (Matthijs et al., 1997). Results of simulations using different numbers of tanks showed that a good approximation of the peak shape at the end of the study river reach was achieved with 47 tanks (Fig. 3). The average length of each tank was about $500 \mathrm{~m}$.

Conversion processes are described by a simplified version of RWQM1, selecting relevant processes according to (Vanrolleghem et al., 2001). The same LAS removal mechanism as for ASM1 was added to the model. The LAS effluent concentration was mainly influenced by the first-order degradation constant. The value found by 'trial and error' calibration for this parameter was $0.085 \cdot h^{-1}$, close to the values found for the Lambro by Gandolfi and Facchi (1998) and Whelan et al. (1999), and in the range of literature values (Boeije et al., 2000). Results are shown in Fig. 4.

\section{Integrated simulations}

The integrated model allows the evaluation of the effect of an upgrade at the plant (realized in July 1998) on LAS concentrations in the river. From Fig. 5 it is clear that the upgrade of the plant, consisting of a $100 \%$ increase in the primary settling volume and a $50 \%$ increase in the aeration tank and secondary settling tank volumes, will have a positive effect on the water quality of the Lambro River during dry weather. The background concentration of LAS decreases due to the discharge of both LAS and heterotrophic bacteria from the WWTP, which means 

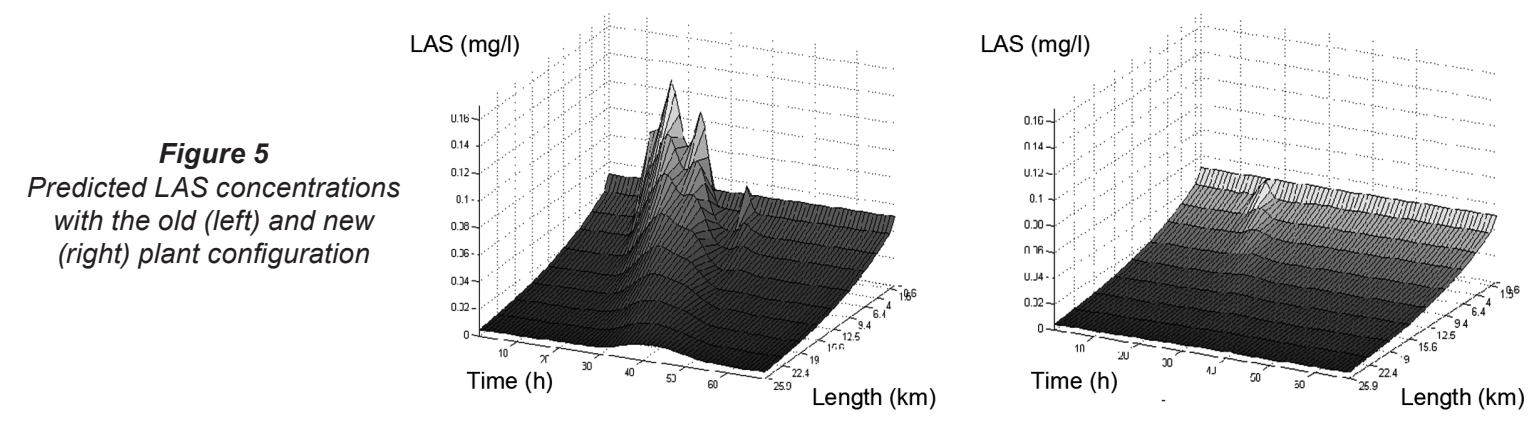

that LAS degradation continues in the river.

Even though no data are available to calibrate the RWQM1, its default values allow qualitative judgement of the effect of WWTP upgrades on the water quality. Although the model was not calibrated to predict ammonia or oxygen concentrations, the effect of the plant upgrade is also clear in the results (not shown). The amount of ammonia entering the river is much lower due to the larger fraction of water treated. Also, oxygen depletions were reduced, while nitrate concentrations were predicted to increase since only little denitrification takes place in the current treatment plant.

\section{Conclusions}

An integrated model of the WWTP of Merone and the Lambro River was created with the aid of an interface between the ASM1 and RWQM1 models. Inherent features of this interface are its closed mass and elemental balances. The COD fractions of ASM1 were split into various sub-fractions for input to RWQM1, while balance-state variables were used to close elemental balances. Also, the different environmental conditions in the AS system and the river system were taken into account. A simple tanks-in-series model was able to adequately describe dispersion in the Lambro River using Boron as a tracer. In addition, LAS data were modelled sufficiently well and the firstorder degradation constant found for LAS is within the range of degradation constants found in the literature and close to the value found in other studies on the same river. As an example of model application, the integrated model was used to simulate the effects of an upgrade of the undersized Merone WWTP. Simulation results show a clear improvement in river water quality with the upgraded plant, both for LAS and traditional pollutants.

\section{Acknowledgements}

The results presented in this publication have been elaborated in the EU projects CD4WC, contract no EVK1-CT-2002-00118 and Harmoni-CA, contract no EVK1-CT-2002-20003. The programme is organised within the Energy, Environment and Sustainable Development Programme in the $5^{\text {th }}$ Framework Programme for Science Research and Technological Development of the European Commission. The authors would like to thank the staff at the Merone WWTP for the supply of data.

\section{References}

ALEX J, KOLISH G and KRAUSE K (2002) Model structure identification for wastewater treatment simulation based on computational fluid dynamics. Water Sci. Technol. 45 (4-5) 325-334.

BENEDETTI L, MEIRLAEN J and VANROLLEGHEM, PA (2004) Model connectors for integrated simulations of urban wastewater systems. In: Bertrand-Krajewski J-L, Almeida M, Matos J and Abdul-Talib S (eds.) Sewer Networks and Processes within Urban
Water Systems. IWA Publishing, London. 13-21

BOEIJE G, SCHOWANEK D and VANROLLEGHEM PA (1998) Application of the SimpleTreat chemical fate model to single-sludge biological nutrient removal waste water treatment plants. Water Sci. Technol. 38 (1) 211-218.

BOEIJE G, SCHOWANEK D and VANROLLEGHEM PA (2000) Incorporation of biofilm activity in river biodegradation modelling: A case study for linear alkylbenzene sulphonate (LAS). Water Res. 33 (6) 1479-1486.

BROWN LC and BARNWELL TO (1987) The Enhanced Stream Water Quality Models QUAL2E and QUAL2E-UNCAS: Documentation and User Manual. Environmental Research Laboratory. US EPA, Athens, GA.

DEKSISSA T, ASHTON PJ and VANROLLEGHEM PA (2003) Control options for river water quality improvement: A case study of TDS and inorganic nitrogen in the Crocodile River (South Africa). Water SA 29 (2) 209-217. http://www.wrc.org.za/archives/ watersa\%20archive/2003/april/14.pdf

EKAMA GA and WENTZEL MC (2004) Modelling inorganic material in activated sludge systems. Water SA 30 (2) 153-174. http://www. wrc.org.za/archives/watersa\%20archive/2004/Apr-04/3.pdf

ERBE V and SCHÜTZE M (2005) An integrated modelling concept for emission-based management of sewer system, wastewater treatment plant and river. Water Sci. Technol. 52 (5) 95-103.

FÉRAY C and MONTUELLE B (2002) Competition between two nitrite-oxidizing bacterial populations: a model for studying the impact of wastewater treatment plant discharge on nitrification in sediment. FEMS Microbiology Ecology 42 (1) 15-23.

FOCHT DD and VERSTRAETE W (1977) Biochemical ecology of nitrification and denitrification. In: Alexander M (ed.) Advances in Microbial Ecology. Plenum Press, New York. 135-214.

GANDOLFI C and FACCHI A (1998) Italian Subgroup Interim Activity Report, January 1998-June 1998 - GREAT-ER Project.

HENZE M, GUJER W, MINO T and VAN LOOSDRECHT MCM (2000) Activated Sludge Models ASM1, ASM2, ASM2d and ASM3. IWA Publishing, London.

MARYNS F and BAUWENS W (1997) The application of the Activated Sludge Model No.1 to a river environment. Water Sci. Technol. 36 (5) 201-208.

MATTHIJS E, HOLT MS, KIEWIET A and RIJS GBJ (1997) Fate of surfactants in activated sludge waste water treatment plants - Outcome of field studies. Tenside Surfactants Detergents 34 238-241.

MEIRLAEN J, HUYGHEBAERT B, SFORZI F, BENEDETTI L and VANROLLEGHEM PA (2001) Fast, simultaneous simulation of the integrated urban wastewater system using mechanistic surrogate models. Water Sci. Technol. 43 (7) 301-309.

RAUCH W, AALDERINK H, KREBS P, SCHILLING W and VANROLLEGHEM PA (1998) Requirements for integrated wastewater models - driven by receiving water objectives. Water Sci. Technol. 38 (11) $97-104$.

RAUCH W and HARREMOËS P (1999) Genetic algorithms in real time control applied to minimise transient pollution from urban wastewater systems. Water Res. 33 (5) 1265-1277.

REDA A (1996) Simulation and Control of Stormwater Impacts on River Water Quality. Ph.D. thesis, Imperial College London, UK.

REICHERT P, BORCHARDT D, HENZE M, RAUCH W, REICHERT P, SOMLYÓDY L and VANROLLEGHEM PA (2001) River Water Quality Model No.1: II. Biochemical process equations. Water Sci. Technol. 43 (5) 11-30. 
SCHÜTZE M, BUTLER D and BECK B (1999) Optimisation of control strategies for the urban wastewater system - an integrated approach. Water Sci. Technol. 39 (9) 209-216.

SOLVI A-M, BENEDETTI L, VANDENBERGHE V, GILLÉ S, SCHLOSSELER P, WEIDENHAUPT A and VANROLLEGHEM PA (2006) Implementation of an integrated model for optimised urban wastewater management in view of better river water quality: A case study. In: Proc. IWA World Water Congress 2006. 10-14 September, Beijing, China.

TAYLOR S, WILLIAMS W, MURREL K and BERISLAV T (2000) Status and development plans for the integrated catchment simulator. In: Proc. IMUG2000. 12-14 April 2000, Prague, Czech Republic.

VANHOOREN H, MEIRLAEN J, AMERLINK Y, CLAEYS F, VANGHELUWE $H$ and VANROLLEGHEM PA (2003) WEST: Modelling biological wastewater treatment. J. Hydroinf. 5 (1) 27-50.
VANROLLEGHEM PA, BORCHARDT D, HENZE M, RAUCH W, REICHERT P, SHANAHAN P and SOMLYÓDY L (2001) River Water Quality Model No.1: III. Biochemical submodel selection. Water Sci. Technol. 43 (5) 31-40.

VANROLLEGHEM PA, BENEDETTI L and MEIRLAEN J (2005a) Modelling and real-time control of the integrated urban wastewater system. Environ. Modell. Softw. 20 427-442.

VANROLLEGHEM PA, ROSEN C, ZAHER U, COPP J, BENEDETTI L, AYESA E and JEPPSSON U (2005b) Continuity-based interfacing of models for wastewater systems described by Petersen matrices. Water Sci. Technol. 52 (1-2) 493-500.

WHELAN MJ, GANDOLFI C and BISCHETTI GB (1999) A simple stochastic model of point source solute transport in rivers based on gauging station data with implications for sampling requirements. Water Res. 33 (14) 3171-3181. 